\title{
Mechanical behaviour of silty clay loam/peat mixtures: cyclic compression-release tests and effects of initial water content
}

\author{
Laure Vidal-Beaudet*, Sylvain Charpentier \\ Laboratoire de sciences des sols et des substrats, INH, 2, rue Le Nôtre, 49045 Angers cedex. France
}

(Received 24 February 1998; accepted 10 June 1998)

\begin{abstract}
The mechanical properties of a silty clay loam (SCL), alone or amended with 20 or $40 \%$ by volume of spaghnum peat, were studied at different values of water content. Cyclic uniaxial compression tests were applied using pressures of $30-500 \mathrm{kPa}$. The void ratios in the last 80 cycles are well represented by a simple function which assumes a limit value for an infinite number of cycles. The void ratio of moist or very moist silty clay loam compressed at $500 \mathrm{kPa}$ is increased to about 55 and $115 \%$ for 20 and $40 \%$ peat contents, respectively. A comparison of the cyclic test with an oedometer (consolidometer) test yields similar results under unsaturated conditions. When the initial degree of saturation is greater than 0.5 and the initial void ratio is greater than 0.9 , the compactibility is seen to increase for all the studied materials. A mixing model is used to study SCL and organic matter interaction under different water saturation conditions. (@ Inra/Elsevier, Paris.)
\end{abstract}

neoluvisol / peat / mechanical properties / porosity

Résumé - Comportement mécanique de mélanges limon argileux - tourbe blonde : essais sous chargements répétés et effets de la teneur en eau initiale. Le comportement mécanique d'un limon argileux, seul ou en mélange volumique avec $20 \%$ ou $40 \%$ de tourbe blonde est étudié pour différentes humidités initiales. Les matériaux sont soumis à 100 cycles de chargement-relâchement et des intensités de compression de 30 à $500 \mathrm{kPa}$. Une fonction simple permet de représenter correctement la variation d'indice de vide sur les 80 derniers cycles et de proposer une valeur de tassement pour un nombre de cycles infini. L'ajout de $20 \%$ et $40 \%$ de tourbe améliore l'indice de vide du limon compressé à $500 \mathrm{kPa}$ de respectivement $55 \%$ et $115 \%$ pour les fortes humidités initiales. La comparaison du test à chargements répétés avec un test de compressibilité œedométrique donne des tassements similaires tant que les conditions sont non saturées. Pour tous les matériaux, la compression est importante pour un taux de saturation initial supérieur à 0,5 et un indice de vide initial supérieur à 0,9 . L'utilisation d'un modèle de mélange permet de proposer des hypothèses d'interaction entre les composants en fonction de la teneur en eau initiale. (C) Inra/Elsevier, Paris.)

néoluvisol / tourbe / propriétés mécaniques / porosité

Communicated by Gérard Guyot (Avignon)

* Correspondence and reprints

E-mail: Laure.Beaudet@angers.inra.fr 


\section{INTRODUCTION}

In the present-day framework of green space planning, great importance is attached to the technical and economic aspects of soil reconstitution. In the areas around a megapolis such as Paris, considerable volumes of soil are displaced or reconstituted. Landscaping companies estimate that one million cubic metres per year of soil are currently being processed in the Paris region. However, due to the limited nature of the resource and the important financial stakes involved, these operations should not deteriorate the agronomic soil quality.

In such planning projects, soil reconstitution is carried out by earth moving equipment using a minimum workforce, so the soils may undergo important phases of loading. To ensure that vegetation is planted under favourable conditions for growth, the agronomist should seek a trade off between 1) checking the physical and agronomic properties of the soils and 2) the technical and economic constraints imposed by the reconstitution project site.

The study of soil compaction phenomena is an important discipline in civil engineering. Before the construction work is started, an optimal consolidation is sought for the materials on site in order to obtain a maximum stability and service life for the structure. By contrast, the agronomist is interested in soil compaction with the aim of maintaining a suitable porosity for plant growth. Many authors have already studied soil consolidation (or compactibility) as a function of the nature of the mineral constituents [7], the initial volumetric water content [14], the intensity of the applied compressive stress [10] and the content in organic matter $[9,18]$. The increase in the number of loadings on the soil modifies the apparent density profile $[17,12]$ and has a deleterious effect on the whole set of physical and mechanical properties in the topmost $30 \mathrm{~cm}$ of soil.

The drained pore volume [24] and hydraulic conductivity under saturated conditions $[22,11]$ are both seen to decrease while the penetration resistance increases $[6,15]$. Consolidation of a soil reduces its aeration, increases its mechanical strength and restricts the length and density of roots $[1,25]$. Root development is strongly inhibited by a soil penetration resistance of the order of $2.5 \mathrm{MPa}$ [11] or a dry-basis apparent density higher than $1.7 \mathrm{Mg} \cdot \mathrm{m}^{-3}$ [16]. Current procedures for the maintenance or improvement of physical properties in reconstituted or strongly reworked soils often involve large inputs of organic matter. However, the choice of type of material or the quantities to be added remain somewhat empirical.

The aim of the present study was to investigate the mechanical behaviour of a surface soil horizon in the Paris Basin following major reworking, either taking the material alone or mixed with peat. The samples were subjected to cycles of repeated loading in an attempt to reproduce the successive and short-lived stresses suffered by urban or suburban soils. The results of this simulation of soil deformation during its emplacement and under cultivation are compared with a conventional oedometric test. The compactibility as well as the addition of peat and the initial water content of the material are studied in terms of their effect on porosity (void ratio) and consolidation resistance. A mixing model is then used to analyse the interactions between the components of the mixture as a function of water content.

\section{MATERIALS AND METHODS}

\subsection{Soil and organic materials}

The silty clay loam (SCL) used in this study is a neoluvisol [2] sampled from near-surface horizons. The main physical and mechanical characteristics of this material indicate that it is representative of the volumes of earth currently involved in planning and development works in the Paris region (table I).

The SCL was sampled by mechanical shovel from a 2-m-thick storage heap of SCL formed by stripping the topmost $30 \mathrm{~cm}$ from arable farming land during work on a high speed train (TGV East) construction site at Villecresnes to the southeast of Paris. The few cubic metres of SCL sampled in this way were then transported by lorry over a distance of $250 \mathrm{~km}$, ground up in a 
Table I. Physical and mechanical characteristics of silty clay loam.



trommel and finally sieved through a screen of mesh size $20 \mathrm{~mm}$.

The added organic material, which originates from the Baltic region, is a fibrous moss peat containing sphagnum. It yields a true density of $1.58 \mathrm{Mg} \cdot \mathrm{m}^{-3}$ (determined by pycnometer, using petroleum ether [3]). In contrast to many other sources of organic matter, this material is widely used as a horticultural substrate and has the advantage of being homogeneous, of constant quality and available in large amounts.

\subsection{Sample preparation}

The earthy material is prepared by mixing the SCL with 20 and $40 \%$ by volume of peat, which corresponds to 2.8 and $5.6 \%$ by weight of the SCL dried at $105^{\circ} \mathrm{C}$, respectively. The mixtures are designated by the labels $120 \mathrm{tbl}$ and $140 \mathrm{tbl}$, which refer to their percentage content of peat moss. Mixing is performed in a concrete mixer using slightly moist materials (water content of the order of $0.15 \mathrm{~m}^{3} \cdot \mathrm{m}^{-3}$ ) in order to obtain optimal homogenisation.

Usually, consolidation tests are carried out according to a standardised oedometric test procedure [4]. The standard oedometric cell is suitable for samples containing aggregates that are less than $5 \mathrm{~mm}$ in diameter. The materials tested in this study are coarser grained, with aggregates reaching sizes of up to $20 \mathrm{~mm}$. To treat this type of sample, Plexiglass (PMMA) cells were constructed with a height of $200 \mathrm{~mm}$, an internal diameter of $190 \mathrm{~mm}$ and a wall thickness of $5 \mathrm{~mm}$. Each cell has a wire gauze at its base with a mesh size of $100 \mathrm{~mm}$. During the filling of the cell, the material is moistened by spraying with the required amount of water. Initial height sample is $190 \mathrm{~mm}$. The cell and its contents are then hermetically sealed inside a plastic sack for at least $48 \mathrm{~h}$ in order to achieve equilibration with the water contained in the sample [19]. The amounts of water thus introduced into the sample are determined on the basis of the water retention properties of the SCL and peat, in such a way as to attain volumetric water contents that are the same as in the mineral phase (with water contents of $0.15,0.25,0.35$ and $0.45 \mathrm{~m}^{3} \cdot \mathrm{m}^{-3}$ ) whatever the proportions of SCL and peat in the mixture. The water contents were calculated assuming that the potential versus water content curves of the SCL and the peat can be added together in the mixture. The selected water content values correspond to respective water potentials of $-1000,-50,-3$ and $-1 \mathrm{kPa}$. The volumetric water contents measured on the samples before compression are reported in table II.

\subsection{Sample compression}

The Plexiglass cell containing the moistened sample in water equilibrium is placed in an aluminium mould (figure /). The mould is made up of:

1) a slotted baseplate fitted with an orifice to allow free drainage of water contained in the sample;

2) an aluminium liner around the cell to prevent its rupture when subjected to high stresses; 
Table II. Water contents of samples before compression.

\begin{tabular}{|c|c|c|c|c|c|c|c|c|c|c|c|}
\hline & & \multicolumn{10}{|c|}{ Initial volumetric moisture content sought for the mineral phase $\left(\mathrm{m}^{3} \cdot \mathrm{m}^{-3}\right)$} \\
\hline & & \multicolumn{2}{|c|}{ Dry air } & \multicolumn{2}{|c|}{0.15} & \multicolumn{2}{|c|}{0.25} & \multicolumn{2}{|c|}{0.35} & \multicolumn{2}{|c|}{0.45} \\
\hline & & & & Initial & lumetric & moisture & ontent & asured & $\left.3^{3} \cdot m^{-3}\right)$ & & \\
\hline Material & $\begin{array}{c}\rho_{\mathrm{s}} \\
\left(\mathrm{g} \cdot \mathrm{cm}^{-3}\right)\end{array}$ & mean & $\max$ & mean & $\begin{array}{l}\max \\
\min \end{array}$ & mean & $\begin{array}{l}\max \\
\min \end{array}$ & mean & $\begin{array}{l}\max \\
\min \end{array}$ & mean & $\begin{array}{l}\max \\
\min \end{array}$ \\
\hline Silty clay loam & 2.55 & 0.028 & $\begin{array}{l}0.029 \\
0.028\end{array}$ & 0.142 & $\begin{array}{l}0.140 \\
0.137\end{array}$ & 0.246 & $\begin{array}{l}0.252 \\
0.240\end{array}$ & 0.376 & $\begin{array}{l}0.390 \\
0.368\end{array}$ & 0.458 & $\begin{array}{l}0.465 \\
0.450\end{array}$ \\
\hline $120 \mathrm{tbl}$ & 2.53 & 0.03 & $\begin{array}{l}0.031 \\
0.029\end{array}$ & 0.191 & $\begin{array}{l}0.194 \\
0.187\end{array}$ & 0.255 & $\begin{array}{l}0.261 \\
0.250\end{array}$ & 0.349 & $\begin{array}{l}0.357 \\
0.343\end{array}$ & 0.449 & $\begin{array}{l}0.453 \\
0.445\end{array}$ \\
\hline $140 \mathrm{tbl}$ & 2.50 & 0.033 & $\begin{array}{l}0.034 \\
0.032\end{array}$ & 0.184 & $\begin{array}{l}0.190 \\
0.181\end{array}$ & 0.304 & $\begin{array}{l}0.320 \\
0.289\end{array}$ & 0.373 & $\begin{array}{l}0.411 \\
0.342\end{array}$ & 0.451 & $\begin{array}{l}0.462 \\
0.439\end{array}$ \\
\hline
\end{tabular}

3) a cover having the same shape as the baseplate, but with a hole for the passage of a piston.

The baseplate and the cover are linked together by six threaded rods which ensure the rigidity of the assembly. The tightness between the cell and the different parts of the mould is ensured by toroidal sealing rings. Before placing the aluminium compression plate $(1 \mathrm{~cm}$ thick) between the test material and the mould cover, the surface of the sample is covered by a filter paper in order to limit adhesion and leave the compression plate free to move.

Sample compression is carried out with a universal testing machine (Model DY 38 of MTS Systems S.A., Ivry sur Seine, France) equipped with a $50-\mathrm{kN}$ pressure transducer (resolution of $10 \mathrm{~N}, 0.1 \%$ precision at fullscale deflection) as well as an extensometer for measuring displacements in the range $6-600 \mathrm{~mm}$ with a resolution of $0.01 \mathrm{~mm}$ and a precision of $0.1 \%$. The testing machine is servo-driven by a computerised system (Autotrac 6.30 software developed by MTS Systems S.A., Ivry-sur-Seine, France) which automatically controls the test to be carried out and records the data that are required. The tested material undergoes a mechanical stress of constant intensity by means of a piston that comes up against the compression plate. This plate is directly linked to the displacement sensor of the extensometer and remains continuously in contact with the sample during performance of the test.
In the repeated loading test, each cycle should reproduce the effect of a load passing over the SCL. The load intensity can be made to vary, covering a range from the passage of a pedestrian to that of a lorry wheel. The test cycle comprises a brief loading for 5 s $[13,20]$ followed by a release to $0 \mathrm{kPa}$ for $180 \mathrm{~s}$; the compression-release cycle is repeated 100 times on each tested material and at seven different levels of compressive stress, i.e. at values of $30,60,100,200,300,400$ and $500 \mathrm{kPa}$ distributed over the surface area of the compression plate.

During the conventional oedometric test, a new sample of each material (at different initial water content) is subjected to a constant load for $24 \mathrm{~h}$, followed in some cases by stress release lasting $48 \mathrm{~h}$. A load of greater magnitude is then applied. In the present study, the steps of compression were fixed at 30,60,100,200, $300,400,500,750$ and $1000 \mathrm{kPa}$.

\section{RESULTS AND DISCUSSION}

At each stage of loading or unloading in the test cycle, it is possible to estimate the void ratio of the material from the measured height of the sample and the quantities of material initially introduced into the cell. The void ratio obtained after release from the final loading cycle is denoted as $e_{100}$. 
1 - Extensometer

2 - Test machine piston

3 - Aluminium cover

4 - Compression plate

5 - Filter paper

6 - Plexiglass mould

7 - Aluminium liner

8 - Metal rod

9 - Metal gauze, mesh $100 \mu \mathrm{m}$

10 - Support block for free drainage

11 - Toroidal sealing ring

12 - Drainage outlet

13 - Aluminium plate base

14 - Sample

Figure 1. Consolidation mould containing sample cell.

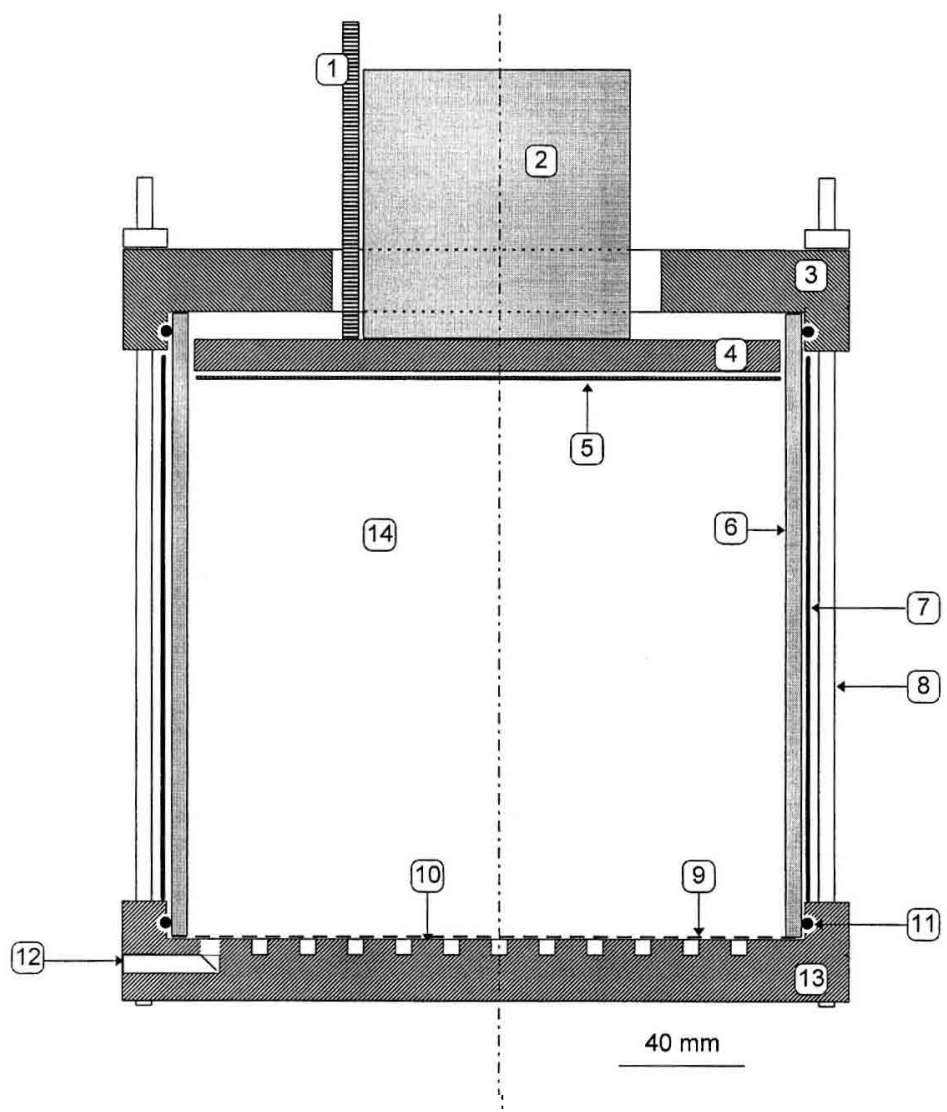

\subsection{Influence of number of cycles on consolidation}

Curves showing the void ratio plotted as a function of the number of cycles exhibit a falling trend, with consolidation tending to a limit value that would be attained at an infinite number of cycles (figure 2). Response curves for repeated loading on granular materials were first studied by Barksdale (in [20]), who proposed the following relation:

$$
e_{1}^{p}(N)=a+b \cdot \log (N)
$$

in which consolidation approaches an infinite value when the number of cycles $N$ tends to infinity. Subsequently, Paute et al. [21] proposed the following:

$$
e_{1}^{p *}(N)=\frac{A \sqrt{N}}{\sqrt{N}+D}
$$

where the consolidation tends to a finite limit, $A$, as $N$ tends to infinity. These latter authors studied the wear of roadways subjected to the repeated traffic of heavy vehicles and used equation (2) in the case of a large number of cycles (10000-100 000).

Equation (2) has been tested using void ratios obtained at the end of release of each cycle. The coefficients $A$ and $D$ are determined by numerical fitting by minimising the mean square error, MSE [23] which is obtained as follows:

$$
\text { MSE }=\frac{\mathrm{SSQ}}{N-\mathrm{np}}=\frac{\sum_{i=1}^{N}\left(o_{i}-a_{i}\right)^{2}}{N-\mathrm{np}}
$$

where $n p$ is the number of parameters fitted in the model and SSQ is the sum of the squared deviations between the observed values and the numerically fitted values, with $o_{i}$ and $a_{i}$ corresponding to the observed and fitted values for the $i$ th cycle. The 


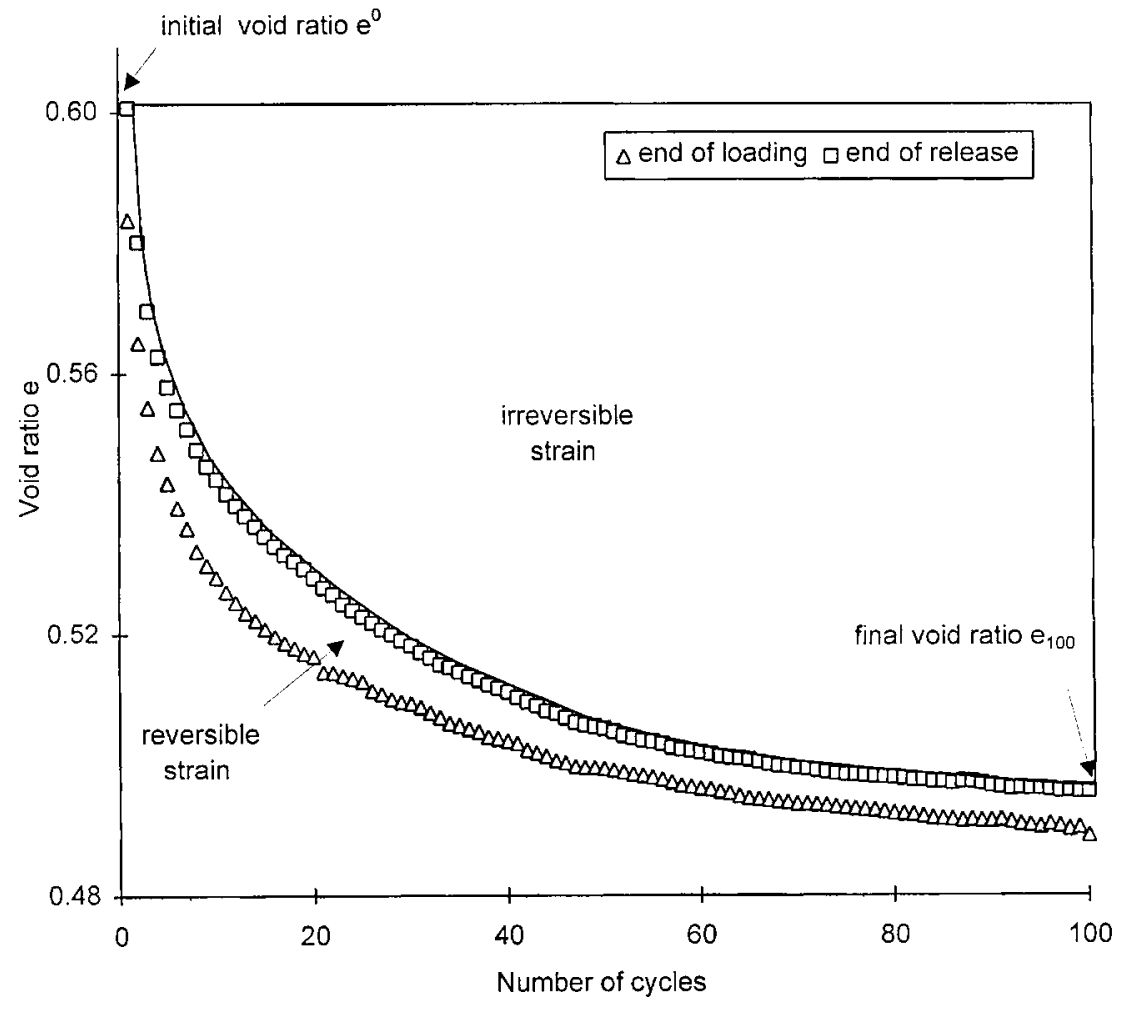

Figure 2. Permanent and reversible strains as a function of number of cycles. fit is based on Newton-Raphson method applied to 100 iterations. An evaluation of the model is carried out by means of the coefficient of determination $r^{2}$ :

$$
r^{2}=1-\frac{\sum_{i=1}\left(o_{i}-a_{i}\right)^{2}}{\sum_{i=1}\left(o_{i}-\sigma\right)^{2}}
$$

where $\bar{o}$ is the mean of the observed values. A value of $r^{2}$ close to unity indicates that the model achieves a good fit for the range of observed values. With the condition $r^{2} \geq 0.99$, equation (2) cannot be fitted with the measured values for all the cycles and all the tested samples. In their tests, Paute et al. [21] eliminated the first 100 cycles corresponding to the emplacement of the sample into the tube. In the present study, we tested this relation by eliminating the first 20 cycles. As a result, all the tested samples yield values of $r^{2} \geq 0.99$.

\subsection{Determination of void ratio $\left(e_{\infty}\right)$ at infinite number of cycles}

The use of equation (2) makes it possible to establish a value of $A$ that corresponds to the limit value $e_{\infty}$ of void ratio (or consolidation) obtained at an infinite number of cycles. The measured and calculated values of void ratio $\left(e_{100}\right.$ and $\left.e_{\infty}\right)$ are compared in figure 3 as a function of the logarithm of the applied load for different initial water contents. For low water contents (samples equilibrated in dry air and with a water content of 0.15 ), the values measured for $\Delta e_{100}=\left(e_{0}-e_{100}\right)$ are at least $95 \%$ of the calculated value $\Delta e_{\infty}=\left(e_{0}-e_{\infty}\right)$, irrespective of the applied compression or the type of material tested. With increasing water content $(0.25,0.35$ and 0.45$)$ and at stresses of $200 \mathrm{kPa}$ or more, the $\Delta e_{100}$ values for the SCL component and all the mixtures attain 80 and $90 \%$ of the $\Delta e_{\infty}$ value, respectively. 
In most cases, the void ratio variations of the $\mathrm{SCL} /$ peat mixtures subjected to around 100 repeated loadings attains, at the end of the test, at least $90 \%$ of the value estimated for an infinite number of loadings. Thus, the choice of 100 cycles appears appropriate for approaching the deformation of SCL mixtures at an infinite number of loadings. For the SCL component, a larger number of cycles would appear indispensable to approach the $e_{\infty}$ limit value. However, the use of the void ratio obtained after 100 cycles does not modify the comparisons with the SCL/peat mixtures since the $e_{100}$ values for the SCL are always less than those determined for the mixtures.

Figure 3 shows that, with the exception of the mixture 120tbl dried in air, the introduction of peat increases the void ratio under all initial water conditions. The $e_{100}$ value for the mixture 140tbl
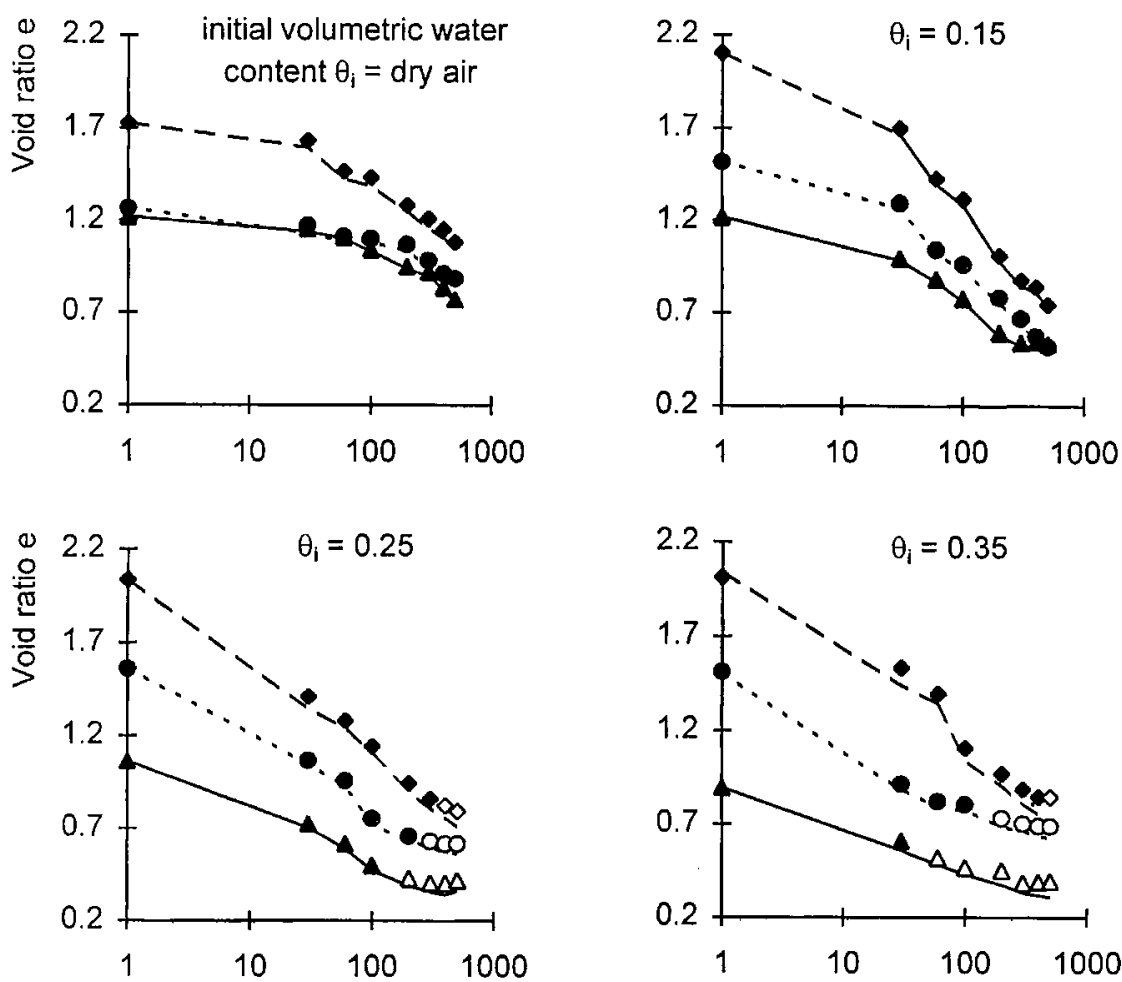

Figure 3. Measured void ratios $e_{100}$ and calculated void ratios $e_{\infty}$ obtained from the Paute et al. [21] equation for silty clay loam alone and for mixtures with 20 or $40 \%$ peat moss, as a function of vertical stress and at all values of water content. The open symbols indicate water saturated samples.
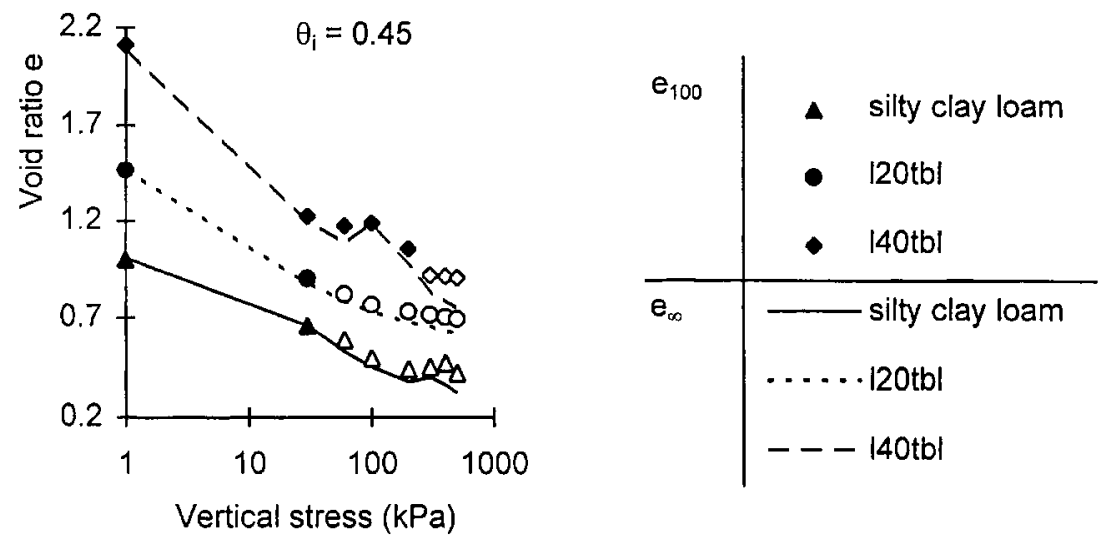
dried in air is $40 \%$ higher than the void ratio for $\mathrm{SCL}$ alone. After compression at $500 \mathrm{kPa}$, the addition of 20 and $40 \%$ of organic matter improves the $e_{100}$ void ratio of the SCL by 5 and $40 \%$, respectively, for an initial water content of 0.15 , and by 60 and $115 \%$ for initial water contents of $0.25-0.45$. Consolidation appears regular for all the samples until loadings are applied where the sample approaches saturation (open symbols on figure 3).

\subsection{Comparison between oedometric test curves and void ratio $e_{100}$ determined from cyclic tests}

Figure 4 presents the oedometric curves obtained for three different materials with an initial water content of $0.25 \mathrm{~m}^{3} \cdot \mathrm{m}^{-3}$. A comparison is made between 1) the strain-stress curve obtained from the oedometric test under free drainage, and 2 ) the values of $e_{100}$ obtained from cyclic tests per-
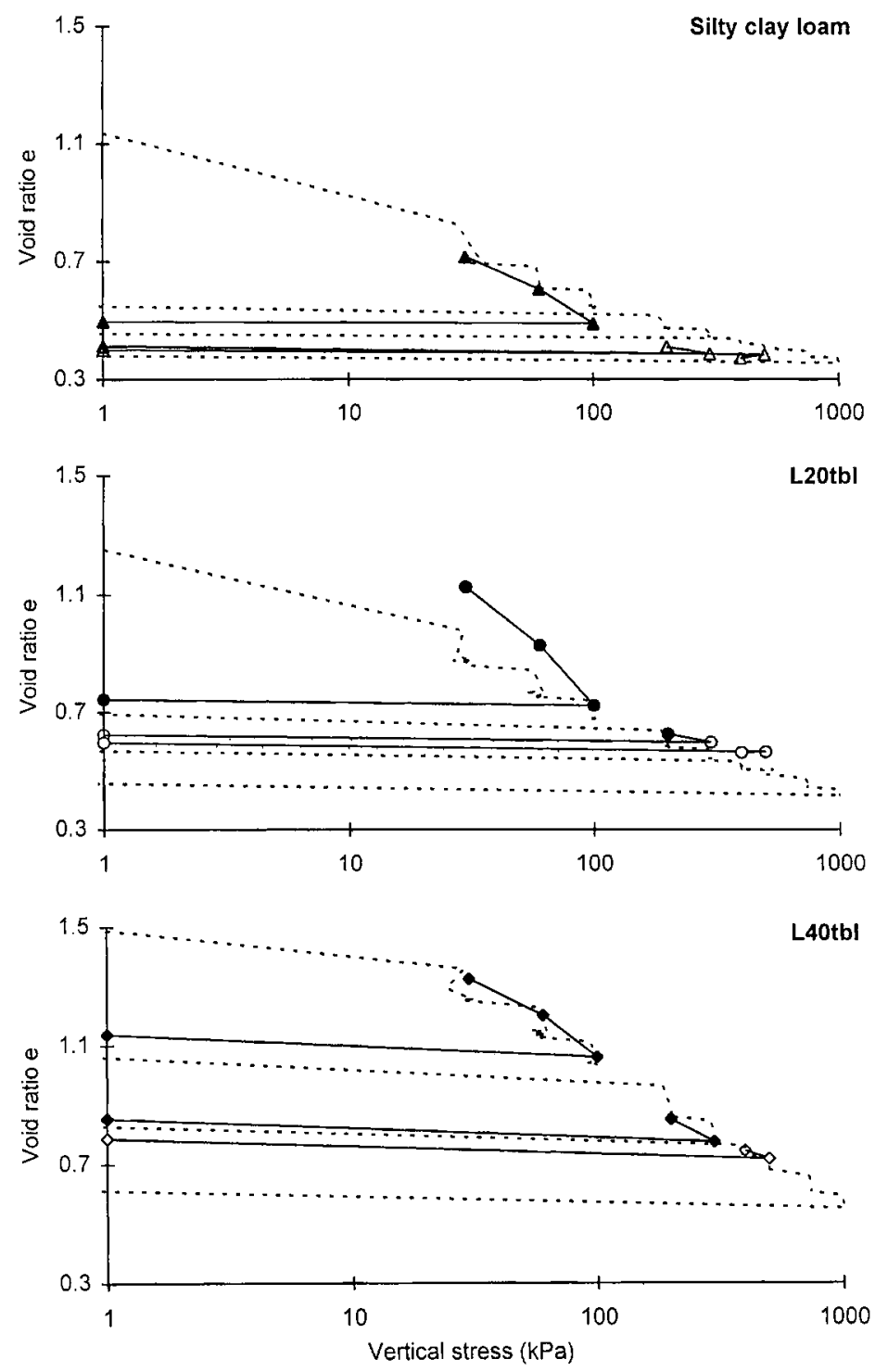

Figure 4. Comparison between void ratio determined from oedometric tests (dotted line) and the $e_{100}$ void ratio (solid line), for an initial water content of $0.25 \mathrm{~m}^{3} \cdot \mathrm{m}^{-3}$. The open symbols indicate water saturated samples. 
formed under different loadings. There is a good agreement between these two types of test. As regards the SCL, the $e_{100}$ values obtained at compressive stresses greater than or equal to $100 \mathrm{kPa}$ are slightly lower than those obtained at constant loading. In the case of mixture 140tbl, the degree of consolidation at constant load is identical to that measured after repeated loadings. The stress paths for both constant and repeated loading tests produce a similar degree of compaction. For mixture 120 tbl, the $e_{100}$ values are higher than those obtained at constant loadings of less than $100 \mathrm{kPa}$. For stresses greater than $300 \mathrm{kPa}$ applied to the SCL and $400 \mathrm{kPa}$ applied to the mixtures, the degree of consolidation - in contradistinction with the oedometric test - does not appear to undergo any further change during the cyclic loading tests. This phenomenon can be observed on all the samples, becoming more apparent with smaller loadings and higher initial water contents.

If we accept that the true water content of the mixtures is probably variable, the considerable amount of water trapped in the pore space of the samples should be taken into account. When water is present in large quantities at the outset of the test (e.g. water content of 0.25 ), it first supports the load and resists consolidation of the sample. As a result, the interstitial water pressure becomes high. During the $24 \mathrm{~h}$ for each stage of loading in the oedometric test, the water has sufficient time to migrate within the sample and flow out via the drainage orifices. When the interstitial stress falls, the sample matrix is deformed and the pore space is modified. During cyclic tests, the durations of loading are very short $(5 \mathrm{~s})$ and the water - which has insufficient time to migrate - forms the phase that resists consolidation of the sample.

\subsection{Void ratio $e_{100}$ and water content at the end of tests}

The degree of water saturation of a medium has a great influence on its susceptibility to compac-
Figure 5. Comparison between void ratios $\left(e_{100}\right)$ for silty clay loam and for mixtures containing 20 and $40 \%$ peat moss, as a function of final volumetric water content, for all vertical stress and using an initial water content of $0.25 \mathrm{~m}^{3} \cdot \mathrm{m}^{-3}$. The open symbols indicate water saturated samples.

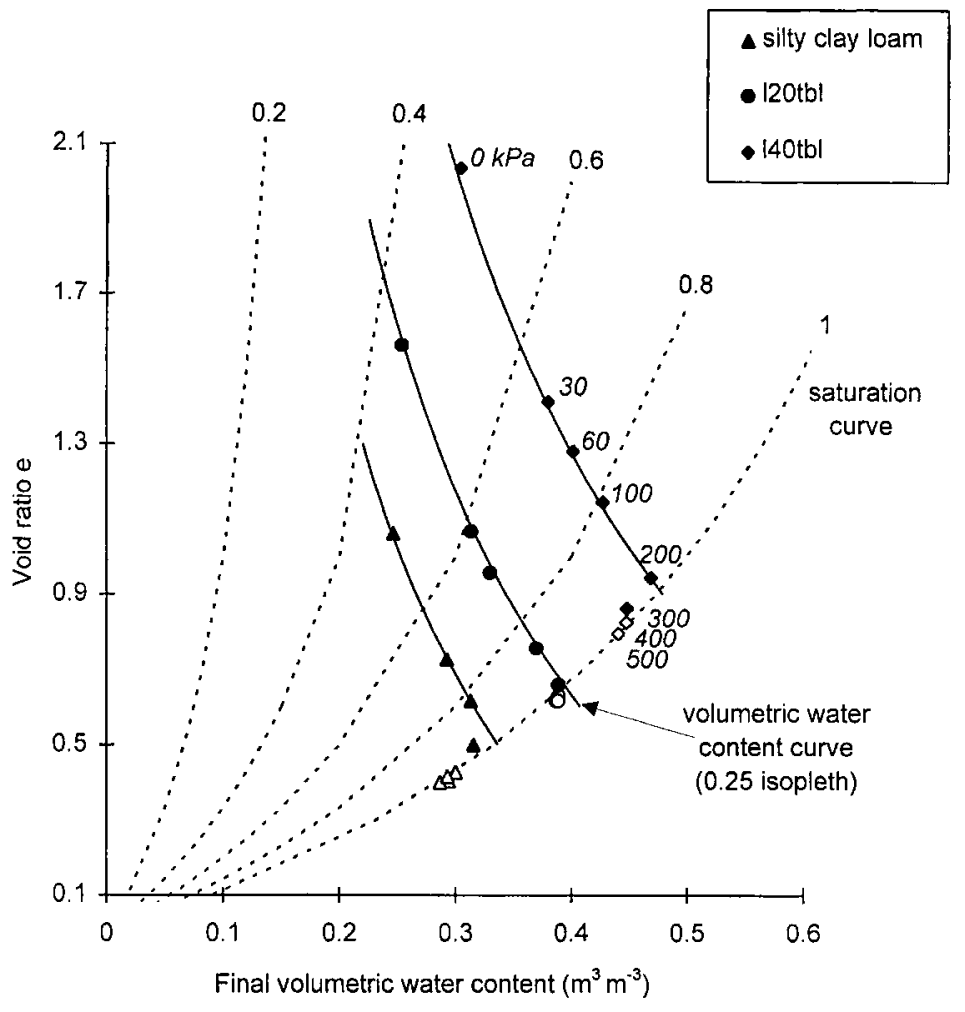


tion. During a consolidation operation which conserves the mass of water in the system, the degree of saturation increases as the void ratio falls. We adopt a diagram (see figure 5) that allows a comparison of the final void ratio with the true volumetric water content at the end of the cycle. The water content at the outset is only involved as a parameter of the initial conditions of the material. A graphical representation is used here for the three materials (plotted also on figure 4), using only samples with an initial water content of 0.25 .

For each mixture, the $e_{100}$ values are plotted for samples having undergone compressions of 0,30 , $60,100,200,300,400$ and $500 \mathrm{kPa}$. These experimental points are compared with the theoretical curves based on the following relations:

$$
e=\frac{\theta_{i}}{\theta}\left(1+e^{0}\right)-1
$$

Assuming that consolidation occurs without drainage, equation (5) links the volumetric water content to the void ratio $e$, where $e^{0}$ is the initial void ratio and $\theta_{i}$ is the initial volumetric water content. In addition, we can write:

$$
e=\frac{\theta}{S_{r}-\theta}
$$

which expresses the variation of $e$ versus $\theta$ for different degrees of saturation $S_{r}$ of the pore volume. The field of variation of equation (5) is limited by the saturation curve $S_{r}=1$.

The compressed samples plot on the corresponding curves for constant initial water content. The representative points are arranged linearly in order of increasing loading, from the highest towards the lowest void ratios. With increased loading, the void ratio of the sample decreases and its volumetric water content shows a correlated rise. For these samples, the good agreement between the measured values and the values calculated from equation (5) supports the hypothesis of conservation of water throughout the different compressions. The samples that drain during loading are water saturated, yielding points that plot as a scattered array near the saturation curve on figure 5 . Nevertheless, this diagram shows evidence for a slight consolidation and drainage during the cyclic loading tests under water saturated conditions, although the loss of water remains limited and is insufficient to bring about a significant stress on the solid phase itself. For an initial water saturation greater than 0.5 and an initial void ratio higher than 0.9 , the degree of consolidation is important in all the studied media.

\subsection{Mixing model for SCL/peat interaction}

On the basis of mixing models proposed by Fiès et al. [8], it is possible to establish various hypotheses for the interaction between SCL and peat as a function of their water content when they are initially mixed. In addition, it becomes possible to check whether these hypotheses remain valid during the consolidation test.

For each value of water content, the SCL and peat components are characterised by:

- their void ratio before compression $\left(e_{s}^{\theta}\right.$ and $e^{()}$) and at $30 \mathrm{kPa}\left(e_{s}^{30}\right)$ and $e_{t}^{30}$, being the first value for which it may be assumed that heterogeneities due to emplacement are removed between all samples;

- their compression index, $C_{s}$ and $C_{1}$, characterised by the slope of the linear regression $e=\mathrm{f}(\log \sigma)$ in the unsaturated part and at $s$ values greater than $30 \mathrm{kPa}$.

For each water content, we may define the following:

$x$ - the ratio of total volume (i.e. solids plus voids) of peat to the sum of the total volumes of peat and SCL;

$V_{\mathrm{s}}$ - the volume of SCL solids;

$V_{1}-$ the volume of peat solids.

For any mixture $x$, we can write:

$$
\begin{aligned}
& V_{t}=\frac{x\left(I+e^{0}\right)}{(I-x)\left(I+e_{s}^{0}\right)} \\
& V_{s}
\end{aligned}
$$

where $e_{s}^{\sigma}$ is the void ratio of SCL alone subjected 
to a loading $\sigma, e_{t}^{\sigma}$ is the void ratio of peat alone subjected to a loading $\sigma$, and $e_{x}^{\sigma}$ is the void ratio of mixture $x$ subjected to a loading $\sigma$.

The following different types of interaction may be envisaged for each value of loading $\sigma$.

- Addition without interaction, where the void ratio of a mixture $x$ can be written as:

$$
e_{x}^{\sigma}=\frac{e_{s}^{\sigma}+e_{t}^{\sigma} \frac{V_{t}}{V_{s}}}{1+\frac{V_{t}}{V_{s}}}
$$

- Double interaction with possibility of penetration of peat into the pore space generated by the SCL and penetration of SCL into the pore space generated by the peat. Let us denote $k_{s}^{\sigma}$ as the proportion of the void ratio generated by rearrangement of the SCL fabric, corresponding to the volume that may be occupied by peat subjected to loading $\sigma$, and $k_{s}^{\sigma}$ as the proportion of the void ratio generated by rearrangement of the peat fabric, corresponding to the volume that may be occupied by SCL subjected to loading $\sigma$.

Three distinct cases may be distinguished:

1) mixtures containing a high percentage of SCL where the peat is able to occupy a part of the pore space generated by rearrangement of the SCL fabric, in so far as $V_{s} k_{s}^{\sigma} e_{s}^{\sigma}>V_{t}\left(e_{s}^{\sigma}+1\right)$

$$
e_{x}^{\sigma}=\frac{e^{\sigma}-\frac{V_{t}}{V_{s}}}{1+\frac{V_{t}}{V_{s}}}
$$

2) mixtures containing a high percentage of peat where the SCL is able to occupy a part of the pore space generated by rearrangement of the peat fabric, in so far as

$$
\begin{array}{r}
V_{t}^{\sigma} k_{t} e_{t}^{\sigma}>V_{t}\left(e_{s}^{\sigma}+1\right) \\
e_{x}^{\sigma}=\frac{e_{t}^{\sigma} \frac{V_{t}}{V_{s}}-1}{1+\frac{V_{t}}{V_{s}}}
\end{array}
$$

3) all intermediate mixtures where

$$
\begin{gathered}
\frac{k_{s}^{\sigma} e_{s}^{\sigma}}{e_{t}^{\sigma}+1}<\frac{V_{1}}{V_{s}}<\frac{k_{t}{ }_{e} e_{t}^{\sigma}}{e_{t}^{\sigma}+1}, \text { with } \\
e_{x}^{\sigma}=\frac{e_{s}^{\sigma}\left(1-k_{s}^{\sigma}\right)-e_{t}^{\sigma}\left(1-k^{\sigma}\right) \frac{V_{t}}{V_{s}}}{1+\frac{V_{t}}{V_{s}}}
\end{gathered}
$$

The values of $e_{1}^{\sigma}$ and $e_{s}^{\sigma}$ are obtained from the following expressions:

$$
\begin{aligned}
& e_{s}^{\sigma}=e_{s}^{30}-C_{s}\left(\log \frac{\sigma}{30}\right) \\
& e_{t}^{\sigma}=e_{t}^{30}-C_{t}\left(\log \frac{\sigma}{30}\right)
\end{aligned}
$$

The results of these two hypotheses concerning SCL/peat interaction are compared with the experimental values by fitting:

- the values of $C_{s}$ and $C_{t}$ in order to minimise the mean square error (equation (3)) between, on the one hand, the functions (12) and (13), and, on the other hand, the experimental values obtained for the pure components at each initial water content;

- the values of $k_{s}^{\sigma}$ and $k_{t}^{\sigma}$ in order to minimise the mean square error (equation (3)) between the functions (9), (10) or (11) for all the samples obtained with the same water conditions and which did not attain water saturation during loading cycles.

Figure 6 shows the results obtained for each of the hypotheses of interaction under three different initial water conditions. These results demonstrate that the hypothesis of double interaction between two components leads to a satisfactory modelling of the behaviour of mixtures under different loadings and with different initial water contents. The interactions that are brought into operation for a given initial water content are maintained when the loading is increased.

The proposed values for the $k_{s}^{\sigma}$ and $k_{t}^{\sigma}$ coefficients (figure 7) indicate a phenomenon that becomes all the more important as the materials 


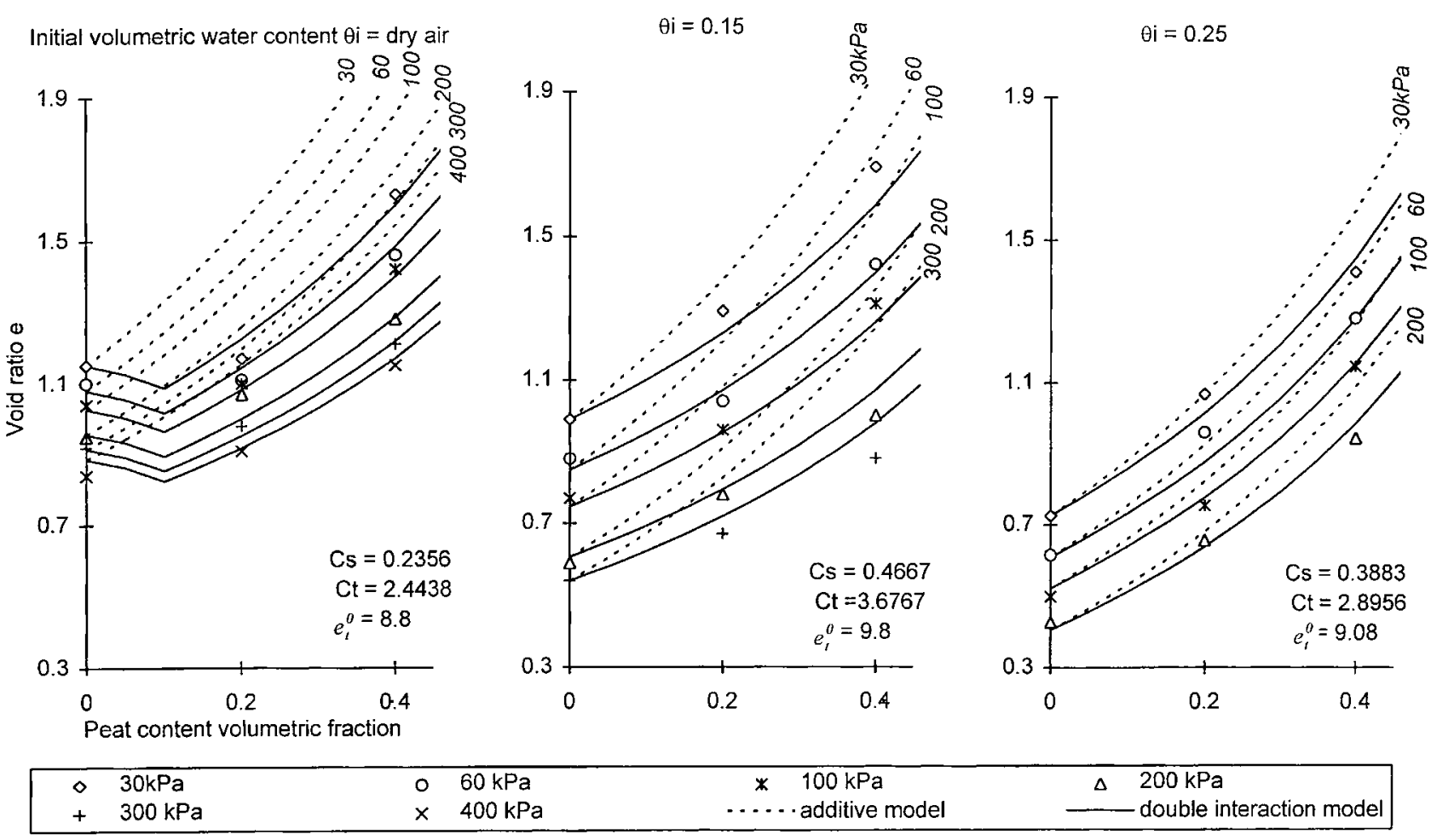

Figure 6. Void ratio plotted as a function of volumetric content of peat at different loadings, for air dry and initial water contents of 0.15 and $0.25 \mathrm{~m}^{3} \cdot \mathrm{m}^{-3}$.

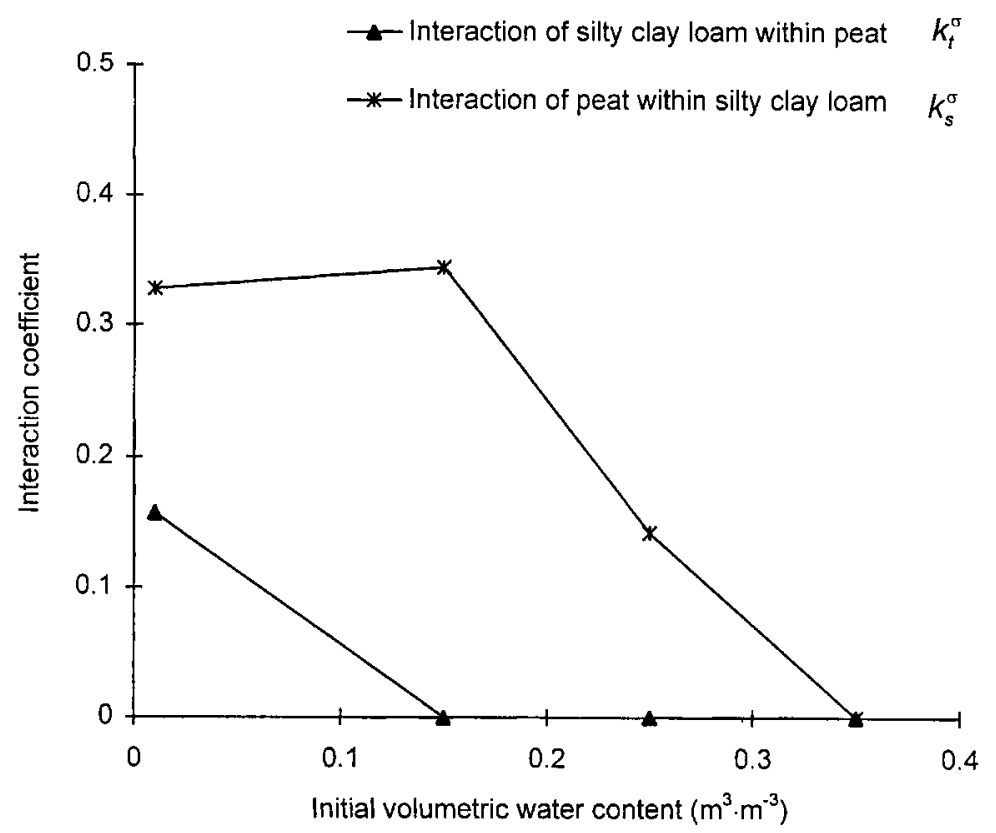

Figure 7. Silty clay loam-peat $k_{\text {, }}^{\sigma}$ and peat-silty clay loam $k^{\sigma}$ interaction coefficients as a function of initial volumetric water content. 
involved are dry. The interaction involving the peat contained in the SCL is only important for dry materials and is even expressed by a lowering of the void ratio at low contents of peat. At initial water contents as low as 0.15 , the peat is sufficiently expanded to prevent its penetration into that part of the pore space generated by the SCL fabric. At this stage, the peat remains rather poorly compacted and its pore volume can still be penetrated by SCL particles. For higher water contents, the interaction weakens and then disappears at 0.35 when the mixture becomes additive.

\section{CONCLUSION}

Consolidation tests with repeated loadings make it possible to predict, for each sample, a finite limit value for compaction as a function of the magnitude of applied mechanical stress as well as the initial volumetric water content. After completing 100 loading cycles, the degree of consolidation of the samples is more than $80 \%$ for the silty clay loam and more than $90 \%$ for the moss peat based mixtures.

For all the moistened samples compressed at more than $100 \mathrm{kPa}$, the silty clay loam alone shows an apparent dry density higher than or equal to $1.7 \mathrm{~g} \cdot \mathrm{cm}^{-3}$ (void ratio less than 0.5 ). Under these conditions, root development is severely inhibited [16] and there is a considerable danger of root asphyxiation. According to Duffy and Mc Clurkin (in [5]), pines planted in an urban zone show a zero regrowth rate when the SCL density is higher than $1.65 \mathrm{~g} \cdot \mathrm{cm}^{-3}$.

The addition of $40 \%$ peat moss improves the void ratio of silty clay loam, yielding a value that is commonly twice as high as observed in SCL alone. The apparent dry density of mixture 140tbl remains always lower than $1.4 \mathrm{~g} \cdot \mathrm{cm}^{-3}$ (void ratio higher than 0.8) in all the tested samples. Under such conditions, the regrowth success rate of pine trees (Duffy and Mc Clurkin in [5]) would be $60 \%$. The peat moss shows a good resistance to compression up to $100 \mathrm{kPa}$, maintaining a satisfactory circulation of water and air within the SCL/peat mixtures. Due to its hydrophilic properties, the peat moss acts as a source of SCL water.
The initial water content has an influence on the arrangement of the pore space of materials. Aggregates of silty clay loam and peat moss display a mixing interaction that varies as a function of the selected degree of moistening. For mixtures prepared in a dry condition, the peat is accommodated between the SCL aggregates and more than $40 \%$ peat by volume is required to improve the void ratio. With increasing water content $(0.15$ and 0.25 ), the SCL aggregates are surrounded by peaty material soaked with water. Moreover, this improvement in void ratio produced by the peat is maintained during consolidation tests. At water contents higher than or equal to 0.35 , the interaction between SCL and peat components weakens and the properties of the mixture are seen to exhibit additive behaviour.

\section{REFERENCES}

[1] Asady G.H., Smucker A.J.M., Compaction and root modifications of soil aeration, Soil. Sci. Soc. Am. J. 53 (1989) 251-254

[2] Baize D., Girard M.C., Référentiel Pédologique, Inra Ed, Paris, 1995.

[3] Blake G.R., Hartge K.H., Particle density, in: Klute (Ed.), Methods of Soil Analysis, Part 1 Physical and Mineralogical Methods, Second Edition, ASA and SSSA, Madison, 381-382, 1986.

[4] Costet J., Sanglerat G., Cours pratique de mécanique des sols : tome 1, Dunod, Paris, 1981.

[5] Craul P., Urban soil in landscape design, John Wiley \& Sons, Inc, New York, 1992.

[6] Culley J.L.B., Larson W.E., Randall G.W., Physical properties of a Typic Haplaquoll under conventional and no-tillage, Soil Sci. Soc. Am. J. 51 (1987) 1587-1593.

[7] Faure A., Contribution à l'étude du mécanisme du compactage des sols, Agronomie 5 (1971) 487-513.

[8] Fies J.C., Henin S., Monnier G., Étude de quelques lois régissant la porosité de matériaux meubles, Ann. Agron. 6 (1972) 621-654.

[9] Guerif J., Rôle de la matière organique sur le comportement d'un sol au compactage. II Matières organiques libres et liées, Agronomie 6 (1979) 469-480.

[10] Guerif J., Mécanismes du compactage, C.R. Acad. Agric. Fr. 1 (1988) 9-28. 
[11] Jorge J.A., Mansell R.S., Rhoads F.M., Bloom S.A., Hammond L.C., Compaction of a fallow sandy loam soil by tractor tires, Soil Sci. 4 (1992) 322-330.

[12] Kirby J.M., Simulating soil deformation using a critical state model: I Laboratory tests, Eur. J. Soil Sci. 45 (1994) 239-248.

[13] Koolen A.J., Deformation and compaction of elemental soil volumes and effects on mechanical soil properties, Soil Tillage Res. 10 (1987) 5-19.

[14] Larson W.E., Gupta S.C., Estimating critical stress in unsaturated soils from changes in pore water pressure during confined compression, Soil Sci. Soc. Am. J. 44 (1980) 1127-1132.

[15] Lowery B., Schuler R.T., Temporal effects of subsoil compaction on soil strength and plant growth, Soil Sci. Soc. Am. J. 55 (1991) 216-223.

[16] Monti P.W., Mackintosh E.E., Effect of camping on surface soil properties in the boreal forest region of northwestern Ontario, Canada, Soil Sci. Soc. Am. J. 43 (1979) 1024-1029.

[17] Moussai B., Étude en laboratoire du compactage statique et de la perméabilité des sols fins argileux, Thèse Insa de Lyon, 1993.

[18] Ohu J.O., Raghavan G.S.V., Mc Kyes E., Mehuys G., Shear strength prediction of compacted soils with varying added organic matter contents, Trans. Am. Soc. Agric. Engng. 2 (1986) 351-355 et 360.
[19] O'Sullivan M.F., Uniaxial compaction effects on soil physical properties in relation to soil type and cultivation, Soil Tillage Res. 24 (1992) 257-269.

[20] Paute J.L., Hornych P., Benaben J.P., Comportement mécanique des graves non traitées, Bull. liaison Labo Ponts et Chaussées 133 (1994) 27-38.

[21] Paute J.L., Jouve P., Martinez J., Ragneau E., Modèle de calcul pour le dimensionnement des chaussées souples, Bulletin liaison Labo Ponts et Chaussées 156 (1988) 21-36.

[22] Reicosky D.C., Voorhees W.B., Radke J.K., Unsaturated water flow through a simulated wheel track, Soil Sci. Soc. Am. J. 45 (1981) 3-8.

[23] Saporta G., Probabilités analyse des données et statistique, Technip, Paris, 1990.

[24 Wagger M.G., Denton H.P., Influence of covercrop and wheel traffic on soil physical properties in continuous no-till corn, Soil Sci. Soc. Am. J. 53 (1989) 1206-1210.

[25] Wiecko G., Carrow R.N., Karnok K.J., Turfgrass cultivation methods: influence on soil physical, root/shoot, and water relationships, in: Carrow R.N., Christians N.E., Shearman R.C. (Eds.), International Turfgrass Society Research Journal 7, Intertec Publishing Corp Overland Park, Kansas, 1993, 451-457. 